\title{
The current state of the plant diversity in the Tlemcen region (Northwest Algeria)
}

\author{
Smaïn El-Amine Henaoui ${ }^{*}$, Mohammed Bouazza \\ Department of Ecology and Environment, Faculty of Natural Sciences and Life and Earth Sciences and the Universe, University of \\ Tlemcen, Tlemcen, Algeria; ${ }^{*}$ Corresponding Author: amine 33 ecoenv@yahoo.fr
}

Received 28 July 2012; revised 11 September 2012; accepted 20 September 2012

\begin{abstract}
Tlemcen region is characterized by a Mediterranean climate, with a remarkable vegetal cover. The latter is influenced by the anthropozoological action. For that, we realized a phytoecological study based on the minimum area classical method [1] which allows us to have a good overview on plant biodiversity and better analyze and interpret the vegetation at different levels (systematic composition; biological, morphological and biogeographical characterizations; stratification; and plant species inventory which we hope comprehensive). The results show that our ecosystems are disrupted because therophytisation, before last vegetation dynamics element [2], settles giving up a few feet of cork and holm oaks species of ancient forest.
\end{abstract}

Keywords: Phytoecology; Plant Diversity; Minimum Area; Anthropic Action; Tlemcen (Western Algeria)

\section{INTRODUCTION}

The nature and actual composition of Mediterranean plant communities cannot be understood without taking into account geological, paleoclimatic and anthropogenic factors that marked the evolution of various ecosystems specific to that biogeographical zone.

The current Mediterranean region can be defined by evident floristic criteria since $50 \%$, of some 25,000 species in the Mediterranean climatic area $[3,4]$ and more so in the Mediterranean bioclimatic zone [5], are endemic [6].

Biodiversity includes three levels of biological variability: ecosystem complexity, species richness and genetic variation [7].

Mediterranean plant biodiversity is the product, for many, of a traditional and harmonious environment use by man [8]. Despite the constant attacks they have suffered, for over a millennium, Mediterranean forests still offer, in some locations, a significant development.
The problem posed by the dynamics of non-tree structures (steppe, shrubland and lawns) can however lead to the understanding that their current expansion has been and is still under the human action impact, mainly through fire and grazing, but also the clearing [9].

In most North Mediterranean countries (France, Spain, etc.) these attacks are somehow controlled and give a biological rise, while in the Southern Mediterranean countries (Algeria, Morocco, Tunisia, etc.) they continue in an uncontrolled manner.

[10] emphasizes that "the analysis of the floristic richness of different groups and their biological and chronological characteristics allows to demonstrate their floral originality, conservation condition and, consquently, their heritage".

The flora of Algeria is characterized by a remarkable level of endemism $(12.6 \%$ or 653 species listed on the 3139 including 7 endemic tree species [11].

However, Tlemcen region is not immune to CircumMediterranean natural laws. It has a very diverse flora and closely linked to various stressors. This vegetation has been largely studied; we can quote [12-16].

\section{LOCATION}

The study is located in the north-western part of Algeria. The study area is divided into two parts: one located in the mountains of Tlemcen and the other near the coast with rugged mountainous terrain (integral part of Traras Mountains). The stations choice mainly depends on the presence of pre-forest formations and shrubland. The area studied is located between $34^{\circ}$ and $35^{\circ} 25^{\prime}$ North and $0^{\circ} 55^{\prime}$ and $2^{\circ} 30^{\prime}$ west and covers a $9017.69 \mathrm{~km}^{2}$ area. It is limited geographically (Figure 1):

- To the north by the Mediterranean Sea,

- In the north-east by the wilaya of Aïn-Témouchent,

- To the east by the wilaya of Sidi-Bel-Abbès,

- To the west by Morocco.

The stations of our study area are: Zarifet, Aïn-Fezza, Nedroma, Ghazaouet, Beni-Saf and Ouled-Mimoun (Figure 1). 


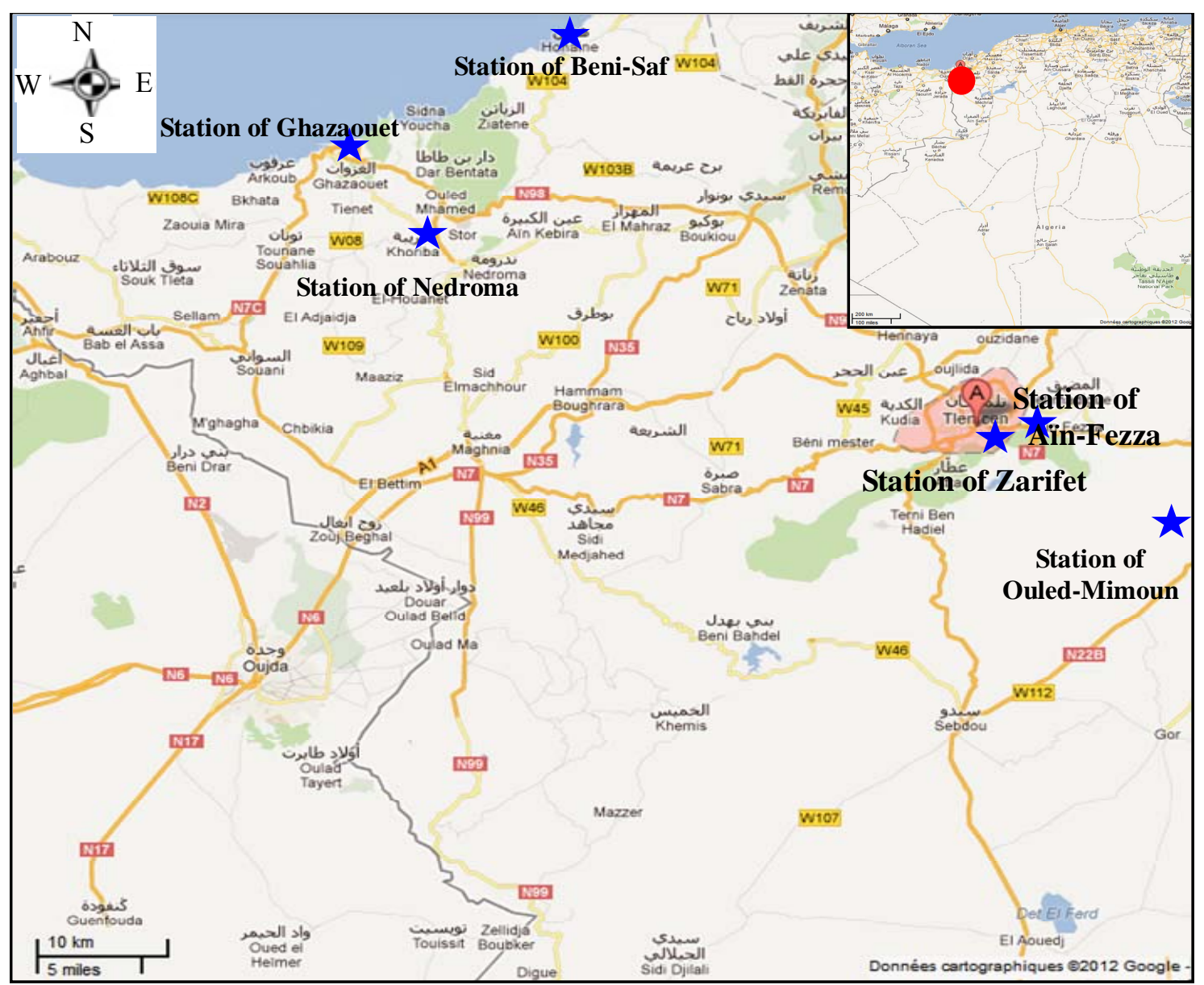

Figure 1. Location of study sites.

The stations were chosen based on the vegetation homogeneity.

\section{MATERIALS AND METHODS}

\subsection{Biological Material}

(See the biological spectrum): biological material.

\subsection{Method}

Four areas and three strata were defined in the ecological zoning. Areas are represented by the soil, climate, species composition and topography. The strata are: the tree layer, shrub layer and herb layer.

Among the different methods of studying vegetation, we used the phytosociological or stigmatist method [1].

The survey includes the list of all species and for each one with its rating of the abundance-dominance, socialbility and reliability.

This minimum area [17] depends on the number of annual species at the time of survey and therefore the vagaries of rainfall and operating conditions [18].

The plant diversity in the Tlemcen region (Northwest Algeria).
For our case, the minimum area for Zarifet and Ghazaouet stations is $128 \mathrm{~m}^{2}$ and for Beni-Saf, Aïn-Fezza, Nedroma and Ouled-Mimoun stations, the area is $64 \mathrm{~m}^{2}$.

The species recovery rate is theoretically defined as the percentage of the soil surface, which would be covered [17]. This rate, variable from one station to another due to the vegetation control, remains very low.

\section{RESULTS AND DISCUSSION Systematic Composition}

Flora used for identification of taxa collected are: the New Flora of Algeria and Southern Desert Regions [11], the Mediterranean Flora [19], The Flora of the Sahara $[20,21]$, the Vast Flora of France in colors [22] and flowers from Algeria [23].

The flora of the study area consists of 322 species or $10.26 \%$ of the flora of Algeria. They belong to the sub branches of gymnosperms and angiosperms, with 62 (42.18\%) and 193 families (18\%) types (Table 2).

Gymnosperms constitute $1.55 \%$ of the study area unlike with angiosperms which largely dominate. They constitute $98.45 \%$ of shrubland with $84.21 \%$ of Eudicots 
and $13.93 \%$ of monocots (Table 1 and Figure 2).

The distribution between the generic and specific families is not homogeneous.

Table 4 and Figure 3 show us that the best represented families, on the generic and specific point of view, are Asteraceae (52), Fabaceae (33), Lamiaceae (25), Liliaceae (17), Poaceae (19), the Boraginaceae (7), Cistaceae (12), the Apiaceae (10), the Euphorbiaceae (11), Oleaceae (8) and Brassica (8).

The floristic includes 55 families, 157 genera and 232 species for Zarifet station. We have 67 species and 61 genera belonging to 30 families in Aïn-Fezza. For Ghazaouet station, we have 46 families, 137 genera with 152 species. Ouled-Mimoun station includes 23 families and 62 genera with 71 species. We have 117 species, 99 genera belonging to 40 families at Beni-Saf. Finally Nedroma station, we have 32 families, 58 genera with 67 species (Table 3).

Table 1. The rates of angiosperms (Eudicots and Monocots) and gymnosperms.

\begin{tabular}{|c|c|c|c|}
\hline \multirow{2}{*}{ Stations } & \multirow{2}{*}{$\begin{array}{c}\text { Gymnosperms } \\
\%\end{array}$} & \multicolumn{2}{|c|}{ Angiosperms } \\
\hline & & $\begin{array}{c}\text { Eudicots } \\
\% \\
\end{array}$ & $\begin{array}{c}\text { Monocots } \\
\% \\
\end{array}$ \\
\hline Aïn-Fezza & 2.99 & 85.07 & 11.94 \\
\hline Ghazaouet & 1.32 & 85.53 & 13.16 \\
\hline O. Mimoun & 2.82 & 84.51 & 12.68 \\
\hline Beni-Saf & 1.71 & 83.76 & 14.53 \\
\hline Nedroma & 1.49 & 82.09 & 16.42 \\
\hline Zarifet & 1.29 & 83.19 & 15.09 \\
\hline Study Area & 1.55 & 84.21 & 13.93 \\
\hline
\end{tabular}

N.B: There is only one species of ferns Pteridium aquilinum (L.) Kuhn belonging to the family of Dennstaedtiaceae (New classification) [24] or Polypodiaceae (Old Classification) [11].

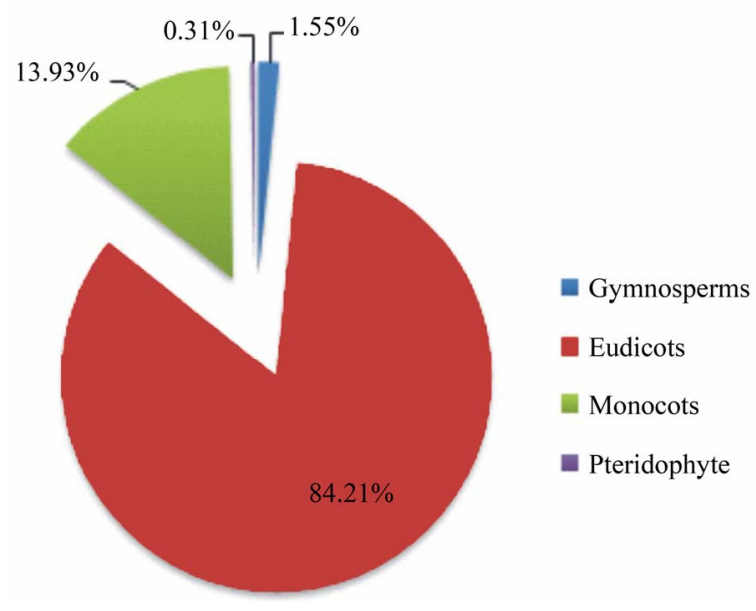

Figure 2. Flora composition by class.

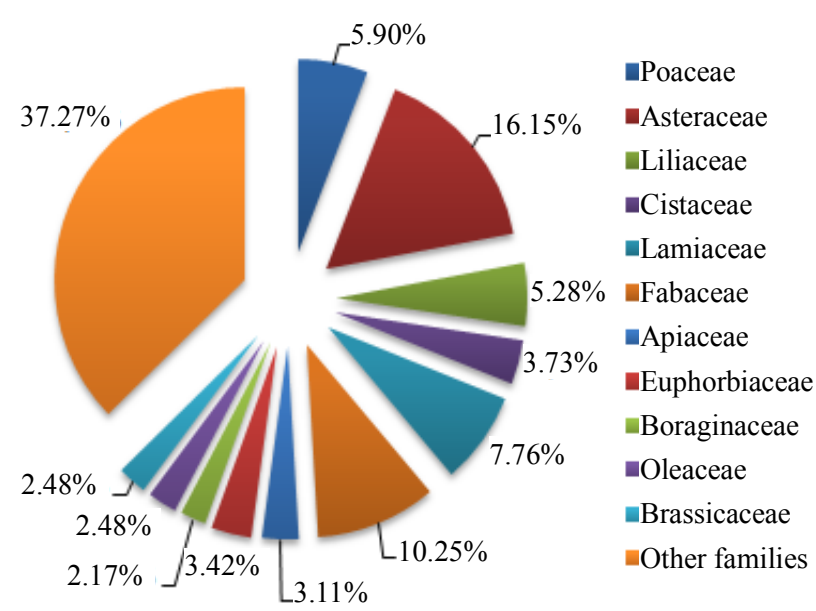

Figure 3. Composition of the flora by family.

\section{BIOLOGICAL CHARACTERIZATION}

\subsection{Biological Types}

For [25] analysis of biological type can give us information on the environment influence on the local vegetation. These biological types are considered to be an experience of coping strategy of flora and vegetation to environmental conditions and allow us to recognize, with respect to the "vascular plants", the following five main biological types: phanerophytes, chamaephytes, hemicryptophytes, geophytes and therophytes.

[26] Highlights the existence of a good correlation between biological types and many phenomorphological characters.

[10] Emphasizes on the abundant flora heritage value. Initiated studies, by [27], have focused on the variation of different ethological types in the sclerophyllous formations in the Mediterranean.

Many other works have been made in order to highlight on one hand the relationship between the distribution of biological types and environmental factors in particular the climate (temperature and rainfall) [28-30] and, on the other hand, the relations between the biological types distribution and "the altitude and the substrate nature" [31].

\subsection{The Biological Spectrum}

The biological spectrum [32] is the percentage of various biological types.

This percentage is substantially the same in regions far away geographically, which show an analogy with living conditions.

[26] Recommends the use of biological spectra as indicators of the distribution of morphological and probably of physiological traits.

Table 5 and Figure 4 show clearly that the distribution 
Table 2. Composition in families, genera and species of flora.

\begin{tabular}{|c|c|c|c|c|c|}
\hline \multicolumn{2}{|c|}{ Families } & \multicolumn{2}{|c|}{ Genera } & \multicolumn{2}{|c|}{ Species } \\
\hline Asteraceae & Crassulaceae & 33 & 1 & 51 & 3 \\
\hline Fabaceae & Violaceae & 20 & 1 & 30 & 2 \\
\hline Lamiaceae & Resedaceae & 15 & 1 & 25 & 2 \\
\hline Poaceae & Solanaceae & 13 & 2 & 18 & 2 \\
\hline Liliaceae & Orchidaceae & 10 & 2 & 17 & 2 \\
\hline Cistaceae & Gentianaceae & 5 & 2 & 12 & 2 \\
\hline Euphorbiaceae & Aristolochiaceae & 3 & 1 & 10 & 2 \\
\hline Apiaceae & Thymeleaceae & 7 & 1 & 9 & 2 \\
\hline Brassicaceae & Pinaceae & 6 & 1 & 7 & 2 \\
\hline Oleaceae & Araceae & 3 & 1 & 6 & 1 \\
\hline Renonculaceae & Acanthaceae & 4 & 1 & 7 & 1 \\
\hline Boraginaceae & Apocynaceae & 5 & 1 & 7 & 1 \\
\hline Caryophyllaceae & Palmaceae & 4 & 1 & 7 & 1 \\
\hline Rosaceae & Buxaceae & 4 & 1 & 5 & 1 \\
\hline Fagaceae & Frankeniaceae & 1 & 1 & 5 & 1 \\
\hline Scrofulariaceae & Zygophyllaceae & 4 & 1 & 4 & 1 \\
\hline Plantaginaceae & Fumariaceae & 1 & 1 & 5 & 1 \\
\hline Primulaceae & Globulariaceae & 1 & 1 & 4 & 1 \\
\hline Cupressaceae & Juncaceae & 2 & 1 & 3 & 1 \\
\hline Iridaceae & Cesalpinieae & 1 & 1 & 4 & 1 \\
\hline Linaceae & Chenopodiaceae & 1 & 1 & 4 & 1 \\
\hline Ericaceae & Plumbaginaceae & 2 & 1 & 3 & 1 \\
\hline Malvaceae & Oxalidaceae & 2 & 1 & 2 & 1 \\
\hline Dipsaceae & Orobanchaceae & 2 & 1 & 3 & 1 \\
\hline Convolvulaceae & Polypodiaceae & 1 & 1 & 3 & 1 \\
\hline Geraniaceae & Asclepiadaceae & 1 & 1 & 2 & 1 \\
\hline Rubiaceae & Rutaceae & 3 & 1 & 3 & 1 \\
\hline Caprifoliaceae & Campanulaceae & 2 & 1 & 3 & 1 \\
\hline Terebinthaceae & Myrtaceae & 1 & 1 & 2 & 1 \\
\hline Rhamnaceae & Salicaceae & 2 & 1 & 3 & 1 \\
\hline Valerianaceae & Papaveraceae & 1 & 1 & 1 & 1 \\
\hline
\end{tabular}


Table 3. Inventory of families as a percentage (Study sites).

\begin{tabular}{|c|c|c|c|c|c|c|}
\hline Families & $\begin{array}{c}\text { Aïn-Fezza } \\
(\%)\end{array}$ & $\begin{array}{c}\text { Ghazaouet } \\
\text { (\%) }\end{array}$ & $\begin{array}{l}\text { O. Mimoun } \\
(\%)\end{array}$ & $\begin{array}{c}\text { Beni-Saf } \\
(\%)\end{array}$ & $\begin{array}{c}\text { Nedroma } \\
(\%)\end{array}$ & $\begin{array}{c}\text { Zarifet } \\
(\%)\end{array}$ \\
\hline Poaceae & 4.48 & 6.58 & 8.45 & 9.40 & 4.48 & 5.17 \\
\hline Asteraceae & 17.91 & 15.79 & 19.72 & 20.51 & 17.91 & 14.66 \\
\hline Liliaceae & 4.48 & 4.61 & 2.82 & 3.42 & 8.96 & 6.47 \\
\hline Cistaceae & 2.99 & 5.26 & 4.23 & 4.27 & 1.49 & 4.74 \\
\hline Lamiaceae & 10.45 & 11.18 & 9.86 & 8.55 & 4.48 & 7.33 \\
\hline Fabaceae & 5.97 & 7.24 & 18.31 & 7.69 & 14.93 & 9.48 \\
\hline Apiaceae & 2.99 & 5.26 & 1.41 & 4.27 & 1.49 & 3.88 \\
\hline Euphorbiaceae & - & 1.97 & 2.82 & 3.42 & 1.49 & 2.59 \\
\hline Boraginaceae & 2.99 & 2.63 & - & 0.85 & 2.99 & 1.72 \\
\hline Oleaceae & 1.49 & 2.63 & 2.82 & 0.85 & 2.99 & 1.72 \\
\hline Brassicaceae & 5.97 & 2.63 & 5.63 & 1.71 & 2.99 & 2.59 \\
\hline Other families & 40.30 & 34.21 & 23.94 & 35.04 & 35.82 & 39.66 \\
\hline
\end{tabular}

Table 4. Floristic composition per family (Study area).

\begin{tabular}{ccc}
\hline Family & Number of species & \% \\
\hline Poaceae & 19 & 5.90 \\
Asteraceae & 52 & 16.15 \\
Liliaceae & 17 & 5.28 \\
Cistaceae & 12 & 3.73 \\
Lamiaceae & 25 & 7.76 \\
Fabaceae & 33 & 10.25 \\
Apiaceae & 10 & 3.11 \\
Euphorbiaceae & 11 & 3.42 \\
Boraginaceae & 7 & 2.17 \\
Oleaceae & 8 & 2.48 \\
Brassicaceae & 8 & 2.48 \\
Other families & 120 & 37.27 \\
\hline
\end{tabular}

of biological types in the vegetation in the same station and between stations is heterogeneous:

- Aïn-Fezza and Ghazaouet stations follow the pattern: $\mathrm{Th}>\mathrm{Ch}>\mathrm{Ph}>\mathrm{He}>\mathrm{Ge}$

- Ouled-Mimoun station follows the pattern: $\mathrm{Th}>\mathrm{Ph}>$ $\mathrm{CH}>\mathrm{He}>\mathrm{Ge}$

- Beni-Saf station follows the pattern: $\mathrm{Th}>\mathrm{Ch}>\mathrm{He}>$ $\mathrm{Ph}>\mathrm{Ge}$
- Nedroma station follows the pattern: $\mathrm{Th}>\mathrm{Ch}>\mathrm{He}$ and $\mathrm{Ph}>\mathrm{Ge}$

- Zarifet station follows the pattern: $\mathrm{Th}>\mathrm{Ch}>\mathrm{Ph}>\mathrm{He}$ and Ge

- The study area follows the pattern: $\mathrm{Th}>\mathrm{Ch}>\mathrm{Ph}>$ $\mathrm{He}>\mathrm{Ge}$

For all the stations studied, therophytes have the highest rate $(39.41 \%)$, reflecting the high population pressure.

In addition to human impacts, the therophytisation traces its beginnings to the phenomenon of desiccation [12,15,33-36]. The latter present therophyty as a form of resistance to drought, and to drylands high temperatures.

Despite the therophytes importance, the chamaephytes keep a particularly important place.

For Zarifet and Ghazaouet stations, the rate of phanerophytes is low, despite a semblance of sylvatic environment. This is mainly due to the floristic richness of these stations, and the recent invasion by therophytes. For Beni-Saf station, the rate of phanerophytes remains very low; the results clearly show its degraded state. It is dominated by therophytes, chamaephytes, hemicryptophytes, phanerophytes and geophytes.

Some authors like [37] explain the abundance of hemicryptophytes, in North Africa, a greater richness in organic matter in forest and elevation. This explains the low percentage, of hemicryptophytes in Ghazaouet station, 
Table 5. Percentage of biological types. (N.S: Number of species).

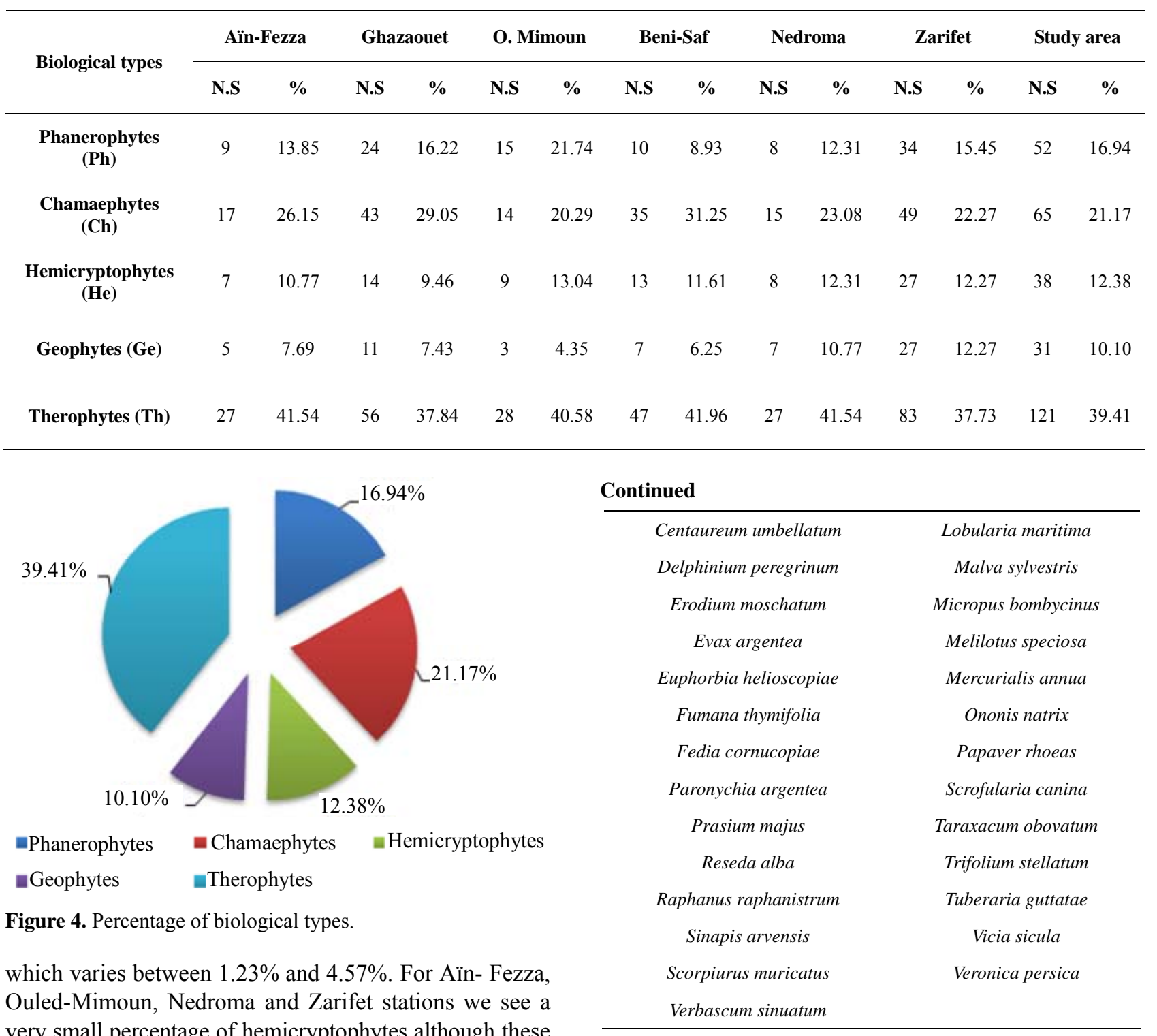
very small percentage of hemicryptophytes although these stations are in a high altitude. Beni-Saf station has a high percentage of hemicryptophytes despite a low altitude.

Among the species encountered, we have:

\begin{tabular}{cc}
\hline Aegilops truncialis & Fagonia cretica \\
Ajuga iva & Galium verum \\
Avena sterilis & Graphalium luteo-album \\
Bromus rubens & Hippocrepis minor \\
subsp. munbyana \\
Brachypodium distachyum & Hordeum murinum \\
Bellis annua & Hirchsfeldia incana \\
Convolvulus althaeoïdes & subsp. adperssa \\
Centaurea pullata & Lagurus ovatus \\
\hline
\end{tabular}

Despite the therophytes importance, the chamaephytes keep an important place in the vegetation of the study area. They are most common in shrub land and are better adapted to drought [38]. They are found in pastures and fields. This distribution is described by [31] in agreement with [28] and [39].

For our case, we recorded a percentage of $21.17 \%$ and among the species encountered, we have:

\begin{tabular}{cc}
\hline Ampelodesma mauritanicum & Globularia alypum \\
Asteriscus maritimus & Galactites tomentosa \\
Atractylis gummifera & Helianthemum helianthemoïdes \\
Chamaerops humilis & Halimium halimifolium \\
subsp. argentea & subsp. halimifolium \\
\hline
\end{tabular}




\section{Continued}

Cistus monspeliensis

Calycotome intermedia

Cistus salviifolius

Daphne gnidium

Daucus carota

Eryngium tricuspidatum

Echinops spinosus

Erica arborea

Erica multiflora

Ferula communis

Frankenia laevis

Phlomis bovei

Reichardia picroïdes

Ruta chalepensis

Sideritis montana

Sedum acre

Senecio vulgaris

Teucrium fruticans

Fumaria capreolata
Helichrysum stoechas

Inula viscosa

Jasminum fruticans

Juncus maritimus

Kundmannia sicula

Lavandula dentata

Lavandula stoechas

Lavandula multifida

Nepeta multibracteata

Pallenis spinosa

Psoralea bituminosa

Thapsia garganica

Ulex boivinii

Ulex parviflorus

Viola arborescens

Viola odorata

Globularia alypum

Galactites tomentosa

Helianthemum helianthemoïdes

Halimium halimifolium subsp. halimifolium

Thymus ciliatus subsp. coloratus

Hemicryptophytes, with a percentage of $12.38 \%$, are still poorly represented in the study area we find:

$\begin{array}{cc}\text { Asperula hirsuta } & \text { Dianthus serrulatus } \\ \text { Atractylis humilis } & \text { Echium vulgare } \\ \text { Anchusa azurea } & \text { Echium parviflorum } \\ \text { Andropogon hirtus } & \text { Echium italicum } \\ \text { Bellis sylvestris } & \text { Geranium sylvaticum } \\ \text { Centaurea soltitialis } & \text { Geranium robertianum } \\ \text { Convolvulus tricolor } & \text { subsp. purpureum } \\ \text { Carduus pycno-cephalus } & \text { Inula montana } \\ \text { Dactylis glomerata } & \text { Leontondon hispidulus } \\ \text { Plantago lagopus } & \text { Marrubium vulgare } \\ \text { Plantago serraria } & \text { Sonchus arvensis } \\ \text { Ranunculus repens } & \text { Salvia verbenaca } \\ \text { Ranunculus bulbatus } & \text { Solenanthus lanatus } \\ \text { Rubia peregrina } & \text { Tragopogon porrifolius }\end{array}$

They seem to increase in forest and high altitude. The dominance of hemicryptophytes is then an obstacle to the installation of phanerophytes.

Despite the low participation of phanerophytes species; they are dominant by their biomass, thus constitute the bushes and forests. They are abundant in the vegetation of Ghazaouet, Ouled Mimoun and Zarifet stations, which still bears witness to the existence of a forest and/or a pre-forest formation.

These are usually Quercetea ilicis species:

\begin{tabular}{|c|c|}
\hline Arbutus unedo & Myrtus communis \\
\hline Buxus sempervirens & Nicotiana glauca \\
\hline Cupressus sempervirens & Olea europea \\
\hline $\begin{array}{l}\text { Cistus ladaniferus } \\
\text { subsp. africanus }\end{array}$ & Pinus halepensis \\
\hline Clematis flammula & Populus alba \\
\hline Crataegus oxyacantha & Pistacia lentiscus \\
\hline Ceratonia siliqua & Pistacia terebinthus \\
\hline Colutea arborescens & Phillyrea angustifolia \\
\hline Fraxinus ornus & $\begin{array}{l}\text { Phillyrea angustifolia } \\
\text { subsp. eu-angustifolia }\end{array}$ \\
\hline Genista tricuspidata & $\begin{array}{c}\text { Phillyrea angustifolia } \\
\text { subsp. media }\end{array}$ \\
\hline $\begin{array}{l}\text { Juniperus oxycedrus } \\
\text { subsp. oxycedrus }\end{array}$ & $\begin{array}{c}\text { Phillyrea angustifolia } \\
\text { subsp. latifolia }\end{array}$ \\
\hline Juniperus phoenicea & Pinus maritima \\
\hline Lonicera implexa & Periploca laevigata \\
\hline Lonicera biflora & Rhamnus lycioïdes \\
\hline Ligustrum japonicum & Rhamnus alaternus \\
\hline Rhus pentaphylla & Viburnum tinus \\
\hline Rosmarinus officinalis & Withania frutescens \\
\hline Rosa sempervirens & Ziziphus lotus \\
\hline Rosa canina & Quercus ilex \\
\hline Robinia pseudo-acacia & Quercus coccifera \\
\hline Rubus ulmifolius & Quercus suber \\
\hline Ricinus communis & $\begin{array}{l}\text { Quercus faginea } \\
\text { subsp. tlemceniensis }\end{array}$ \\
\hline aclinis ar & \\
\hline
\end{tabular}

We note that the absence of nanophanerophytes is certainly linked to severe erosion in the region but, especially, the power of the winds [40].

Finally, geophytes are everywhere; the least repre- 
sented with only $10.10 \%$. Representation of the latter remains higher in the shrub land $(10.77 \%$ in Nedroma) than in the pre-forest formations and forest $(7.43 \%$ in Ghazaouet).

Among this group we have the Liliacaea, the Iridaceae, the Orchidaceae and Araceae represented by the following species:

\begin{tabular}{cc}
\hline Allium roseum & Agropyron repens \\
Asphodelus microcarpus & Ballota hirsuta \\
Aristolochia longa & Bellevallia dubia \\
Aristolochia baetica & Gladiolus segetum \\
Asparagus stipularis & Iris planifolia \\
Asparagus acutifolius & Iris unguicularis \\
Asparagus albus & Iris tingitana \\
Asparagus officinalis & Muscari neglectum \\
Arisarum vulgare & Muscari comosum \\
Ornithogalum umbellatum & Stipa tortilis \\
Ophrys tenthredinifera & Stipa tenacissima \\
subsp. lutescens & Tulipa sylvestris \\
Orchis italica & Urginea maritima \\
Smilax aspera & \\
subsp. altissima & \\
Scilla lingulata &
\end{tabular}

[30] Also found higher geophytes proportions in Mediterranean area than in steppe domain.

The origin of the extension of therophytes is due:

- Either to the adaptation to the winter cold stress $[20,28]$ or to summer drought $[29,34]$.

- Or even to the medium disturbances by grazing, crops, etc. [41].

Indeed, plant formations in dominant phanerophytic vegetal cover have the lowest recovery of therophytes while those, for which the phanerophytes rate is negligible, therophytes recovery is much higher. Similarly, [42] explain the changes of floristic composition and species biological cycle (after cutting the undergrowth of evergreen oak), by the increasing of the lower layers brightness level.

\subsection{Disruption Index}

The disturbance index (calculated according to [43]) quantifies the therophytisation of a medium.

IP $=$ Chamaephytes number + Therophytes number/Species total number
For all stations this index remains high compared to [44] results in Tunisia, where he obtained $70 \%$ as high value. The chamaephytes and therophytes are the biological types that dominate in the region. This shows the anthropozoologic high pressure experienced by vegetation in the study area.

The disturbance index being about $57 \%$ for the entire study area, this shows clearly the sharp decline (Table 6).

\section{MORPHOLOGICAL CHARACTERIZATION}

The sharp deterioration affects species regeneration. The non-regenerating perennial causes changes that give non-resilient paths, and also causes a change in potential output and the botanical composition [45]. The vegetal cover is dominated by three vegetation types: woody perennials, herbaceous perennial and annual grasses.

The morphological point of view, the vegetation of the study area is marked by heterogeneity between woody and herbaceous species and between perennials and annuals. The annual herbaceous species are dominant with a percentage of $50.80 \%$. The herbaceous perennials come in second with $25.72 \%$. In third place we find the woody perennial with a percentage of $23.47 \%$ (Table 7) and (Figure 5).

The intense human impact, which the forests of the region continue to suffer, results in the invasion of therophytes, which are typically annual herbs. Thus, the harsh conditions favor the development of short-cycle herbaceous species at the expense of woody perennials generally more demanding in water and nutritional needs.

\section{STRATIFICATION}

At the study area we have the herbaceous layer, which dominates with a percentage of $75.45 \%$, then the shrub layer with $14.67 \%$ and finally the tree layer with a small percentage that is of the order of $9.88 \%$ (Table 8 ).

The herbaceous layer is generally formed by therophytes which are annual grasses in general (Figure 6).

\section{BIOGEOGRAPHIC CHARACTERIZATION}

The study of the Mediterranean basin flora is of great

Table 6. Index of stations disruption studies/study area. (A.F: Aïn-Fezza, GZT: Ghazaouet, O.M: Ouled. Mimoun, B.S: BeniSaf, NDR: Nedroma and ZRT: Zarifet).

\begin{tabular}{cccccccc}
\hline Stations & A.F & GZT & O.M & B.S & NDR & ZRT & $\begin{array}{c}\text { The } \\
\text { study } \\
\text { area }\end{array}$ \\
\hline IP & $67 \%$ & $66 \%$ & $60 \%$ & $73 \%$ & $64 \%$ & $60 \%$ & $57 \%$ \\
\hline
\end{tabular}


Table 7. Percentage of morphological types in the study area.

\begin{tabular}{ccc}
\hline Morphological types & Number of species & $\mathbf{\%}$ \\
\hline Annual grasses & 158 & 50.80 \\
Herbaceous perennial & 80 & 25.72 \\
Woody perennials & 73 & 23.47 \\
\hline
\end{tabular}

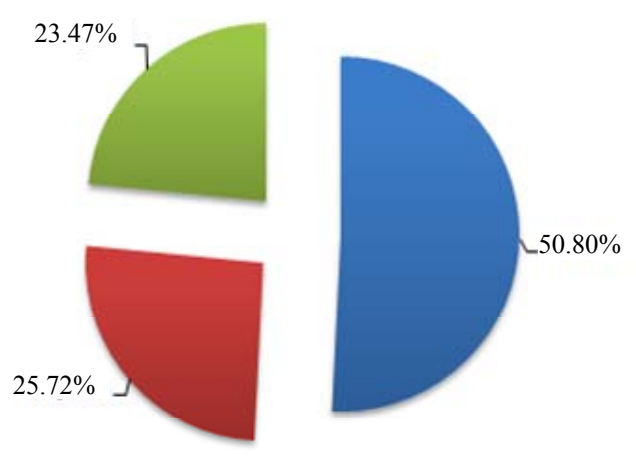

घAnnual grasses $\quad$ Herbaceous perennial $\quad$ Woody perennials

Figure 5. Percentage of morphological types.

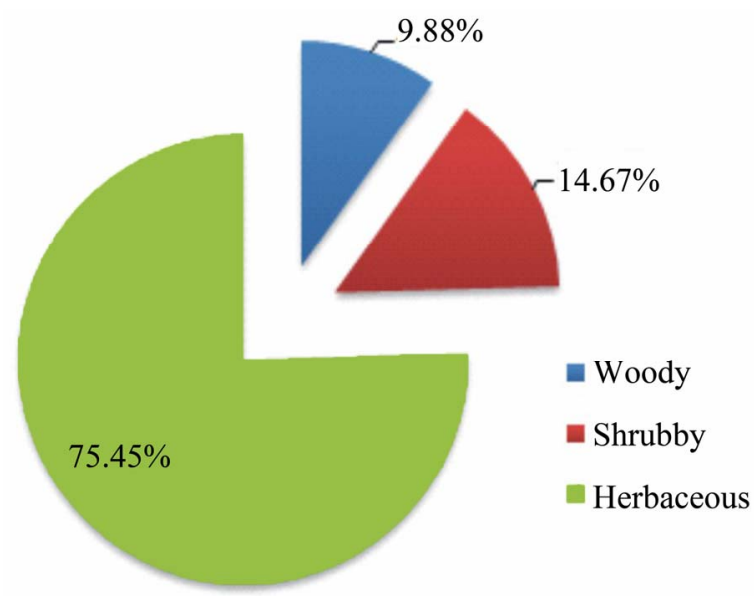

Figure 6. Flora percentage by strata.

interest due to its richness, its high rate of endemism, its diversity related to the heterogeneity of historical, paleogeographic, ecological and geobotanical factors which determine it; as well as the ancient human pressure impact $[39,46-48]$.
Uncertainties remain for some species that are currently having an extension of their ranges.

The distribution of different species surveyed, by phytogeographical element, is very heterogeneous.

Table 9 and Figure 7 hereafter show that:

- The Mediterranean native element is by far the largest with $(43.58 \%)$. It is represented by the therophytes $(14.61 \%)$ and by the woody phanerophytes $(7.30 \%)$ and chamaephytes $(8.63 \%)$.

- The endemism rate is relatively low with (5.06\%). The endemic North African species outnumber the Algerian-Tunisian and/or Algerian-Moroccan species.

\section{CONCLUSIONS}

The Tlemcen region is determined by a remarkable plant biodiversity influenced by many environmental stresses (drought, human action, overgrazing, etc.) which makes it integral part of the Mediterranean.

From the results obtained, we can conclude that all the studied formations are characterized by a dominance of therophytes. The intense human impact, experienced by the vegetation in the area, ends by an invasion of mainly therophytes. The latter characterize the group of Stellarietea Mediae, resulting in a homogenization and trivialization of most floristic formations of this region. Indeed, plant formations in dominant phanerophytic vegetal cover have the therophytes lowest recovery while those for

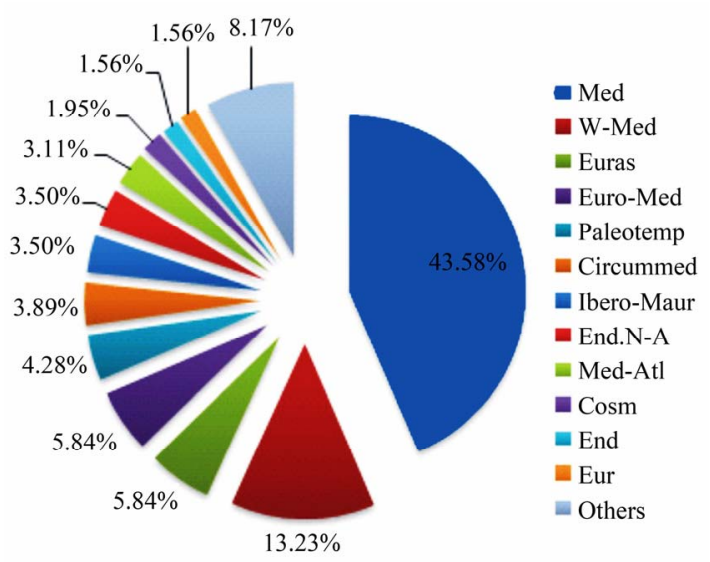

Figure 7. Biogeographical types percentages.

Table 8. Percentage of strata.

\begin{tabular}{ccccccccccccccc}
\hline \multirow{2}{*}{ Strata } & \multicolumn{2}{c}{ Aïn-Fezza } & \multicolumn{2}{c}{ Ghazaouet } & \multicolumn{2}{c}{ O. Mimoun } & \multicolumn{2}{c}{ Beni-Saf } & \multicolumn{2}{c}{ Nedroma } & \multicolumn{2}{c}{ Zarifet } & \multicolumn{2}{c}{ Study area } \\
\cline { 2 - 13 } & N.S & $\%$ & N.S & $\%$ & N.S & $\%$ & N.S & $\%$ & N.S & $\%$ & N.S & $\%$ & N.S & $\%$ \\
\hline Woody & 6 & 8.70 & 15 & 9.49 & 9 & 12.50 & 7 & 6.31 & 4 & 6.78 & 25 & 10.50 & 33 & 9.88 \\
Shrubby & 11 & 15.94 & 29 & 18.35 & 12 & 16.67 & 17 & 15.32 & 15 & 25.42 & 29 & 12.18 & 49 & 14.67 \\
Herbaceous & 52 & 75.36 & 114 & 72.15 & 51 & 70.83 & 87 & 78.38 & 40 & 67.80 & 184 & 77.31 & 252 & 75.45 \\
\hline
\end{tabular}


Table 9. Biogeographic types with species number and percentage.

\begin{tabular}{|c|c|c|c|}
\hline Biogeographic types & Signification & Number & $\%$ \\
\hline Med & Mediterranean & 112 & 43.58 \\
\hline W-Med & W-Mediterranean & 34 & 13.23 \\
\hline Euras & Eurasian & 15 & 5.84 \\
\hline Euro-Med & European-Mediterranean & 15 & 5.84 \\
\hline Paleotemp & Paleotempered & 11 & 4.28 \\
\hline Circummed & Circum-mediterranean & 10 & 3.89 \\
\hline Ibero-Maur & Ibero-Mauritanean & 9 & 3.50 \\
\hline End. N-A & Endemic. North-African & 9 & 3.50 \\
\hline Med-Atl & Mediterranean-Atlantic & 8 & 3.11 \\
\hline Cosm & Cosmopolitan & 5 & 1.95 \\
\hline Subcosm & Subcosmopolitan & 5 & 1.95 \\
\hline Macar-Med & Macaronesian-Mediterranean & 4 & 1.56 \\
\hline End & Endemic & 4 & 1.56 \\
\hline Eur & European & 4 & 1.56 \\
\hline Paleosubtrop & Paleosubtropical & 2 & 0.78 \\
\hline Circumbor & Circumboreal & 2 & 0.78 \\
\hline Ibero-Mar & Ibero-Morrocan & 2 & 0.78 \\
\hline Euras-Med & Eurasian-Mediterranean & 2 & 0.78 \\
\hline N-A & North-African & 2 & 0.78 \\
\hline Sah & Saharian & 1 & 0.39 \\
\hline Sah-Sind & Sahara-Sindian & 1 & 0.39 \\
\hline
\end{tabular}

which the rate of phanerophytes is negligible, the therophytes recovery is much higher.

The disturbance index being about $57 \%$ for the entire study area, this shows clearly the sharp deterioration.

From the morphological point of view, the study area vegetal formations are marked by heterogeneity between woody and herbaceous species and between perennials and annuals. The annual herbaceous species are dominant with a percentage of $50.80 \%$. The herbaceous perennials come in second with $25.72 \%$. In third place we find the woody perennials with $23.47 \%$.

From the phytogeographical point of view, the Mediterranean element is the most dominant with $43.58 \%$.

Finally, conservation of natural heritage remains a major initiative to preserve the region plant biodiversity against a regression which may become irreversible in the near future.

In this regard, Algeria, as all Mediterranean countries, has long been involved in the preservation and conservation of biodiversity policy through the creation of several national parks. Currently, Algeria has eight national parks that include all original landscapes and where are the main hot spots of plant biodiversity in the country [49].
Meanwhile, several research works, mainly focused on the inventory and mapping of this phytobiodiversity, have been done in these hot spot. Among these works, we mention those of [50] in Chrea National Park, [51] and [52] in El-Kala national park, [53] and [54] in Tlemcen National Park. All these works have stressed the importance of such an inventory in the sound management of natural ecosystems. Indeed, several authors suggested that the conservation and enhancement of a natural ecosystem requires a good knowledge of its biodiversity $[49,55]$. Many of these works in these ecosystems have emphasized the rich flora of these environments and have shown a variety of endemic and/or rare species to be placed in conservation priorities. They also discussed the degradation advanced state of these natural ecosystems which is mainly attributed to the combined action of man and his animals (grazing).

\section{REFERENCES}

[1] Braun-Blanquet, J. (1951) The plant communities of Mediterranean France. C.N.R.S., Paris.

[2] Quezel, P. (2000) Reflections on the evolution of the flora 
and vegetation in Mediterranean Maghreb. Ibis Press, Paris.

[3] Emberger, L. (1930) Climate on a formula applicable in botanical geography. Comptes Rendus de l'Académie des Sciences, 1991, 389-390.

[4] Emberger, L. (1930b) The vegetation of the Mediterranean region. Test of a classification of plant communities. The Scientific Journal Revue Générale de Botanique, 42, 341-404, 641-662.

[5] Daget, Ph. (1977) The Mediterranean bioclimate, general characteristics, classification schemes. Vegetatio, 34, 120. doi:10.1007/BF00119883

[6] Quezel, P. (1985) Definition of the Mediterranean region and the origin of its flora. Gomez-Campo Edit- "Plant conservation in the Mediterranean area" Junk, Dordrecht, 9-24.

[7] Robert-Pichette, P. and Gillespie, L. (2000) Monitoring protocols for terrestrial plant biodiversity. Lexicon, Directorate for Science Ecosystems, Environment Canada, Web Site.

[8] Quezel, P. (1999) Plant biodiversity of Mediterranean forests its possible evolution by thirty years. Mediterranean Forest, 20, 3-8.

[9] Quezel, P. (1999) Large structures in the Mediterranean vegetation: Determining factors in their implementation postglacial. Geobios, 32, 19-32. doi:10.1016/S0016-6995(99)80081-3

[10] Dahmani-Megrerouche, M. (1997) The oak in Algeria. Syntaxonomy, phytosociology and stand dynamics. Ph.D. Thesis, University of Science and Technology, Houari Boumediene, Algiers.

[11] Quezel, P. and Santa S. (1962-1963) New flora of Algeria and the desert regions Meridional. French National Center for Scientific Research, Paris.

[12] Benabadji, N., Bouazza, M., Merzouk, A. and Ghezlaoui, S.M. (2004) Appearance of phytoecological atriplexaies north of Tlemcen (Orany-Algeria). Science and Technology, 22, 62-79.

[13] Benabadji, N., Benmansour, D. and Bouazza, M. (2007) The flora of the mountains of Ain Fezza in western Algeria, and biodiversity dynamics. Science and Technologies, 26, 47-59.

[14] Bouazza, M., Benabadji, N. and Loisel R. (2001) Balance of flora in the region of Tlemcen (Orany-Algeria). Mediterranean Forest, 22, 130-136.

[15] Bouazza, M., Benabadji, N., Loisel, R. and Metge, G. (2004) Evolution of the steppe vegetation in the southwest of Orany (Algeria). Critical Reviews in Oral Biology and Medicine, 30, 221-231.

[16] Mesli-Bestaoui, K. (2009) Contribution to an ecological survey and vegetation dynamics of the mounts of Tlemcen by a mapping approach. Thesis, Abou-Bakr Belkaïd University of Tlemcen, Tlemcen.

[17] Guinochet, M. (1973) Phytosociology. Masson Edit, Paris.

[18] Djebaïli, S. (1984) Algerian steppe, Ecology and phytosociology. Odessa Polytechnic National State University, Algiers.
[19] Paccalet, Y. (1981) Mediterranean flora. Hatier, Paris.

[20] Ozenda, P. (1963) Organization and reproduction of angiosperms. In: Abbayes, et al., Eds., Botany: Anatomy, Life Cycles, Systematics, Masson and Cie Eds, Paris, 645-722.

[21] Ozenda, P. (1977) Flora of the Sahara. 2nd Edition, French National Center for Scientific Research, Paris.

[22] Bonnier, G. (1990) The vast flora colors Gaston Bonnier. France, Switzerland, Belgium and neighboring countries, Editions Belin, Paris.

[23] Beniston, N.T. and Beniston, W.S. (1984) Flowers from Algeria. National Book Company, Algiers.

[24] The International Plant Names Index (IPNI). http://www.uk.ipni.org/

[25] Raunkiaer, C. (1907) The life forms of plants and their bearing on geography. In: Raunkiaer, C., Ed., The Life Forms of Plants and Statistical Plant Geography, 1934. (Translated from Danish, with Introduction by A. G. Tansely), Oxford University Press, Oxford, 2-104.

[26] Romane, F. (1987) Distribution efficiency of plant growth forms to anlyse vegetation at the regional scale. Case of some green oak coppice Languedoc. Ph.D. Thesis, State University, Aix-Marseille.

[27] Barbero, M. and Quezel, P. (1989b) Contribution to the study of phytosociological matorrals Eastern Mediterranean. Lazoco, 11, 37-56.

[28] Raunkiaer, C. (1934) The life forms of plants and statistical plant. Geography Claredon Press, Oxford.

[29] Daget, Ph. (1980) On life forms as adaptive strategy. (Case therophytes). In: Barbault, R., Blandin, P. and Meyer, J.A., Eds., Searches of Theoretical Ecology, Adaptive Strategies, Maloines, Paris, 89-114.

[30] Danin, A. and Orshan, G. (1990) The distribution of Raunkiaer life forms in Israël in relation to the environment. Journal of Vegetation Science, 1, 41-48. doi: $10.2307 / 3236051$

[31] Floret, C., Galan, M.J., Lefloch, E., Orshan, G. and Romane F. (1990) Growth forms and phenomorphology traits along an environnemental gradient: Tools for studing vegetation. Journal of Vegetation Science, 1, 71-80. doi: $10.2307 / 3236055$

[32] Gaussen, H., Leroy, J.F. and Ozenda P. (1982) Accurate botanical 2: Higher plants. Edit Masson, Paris.

[33] Sauvage, Ch. (1961) Geobotanical research on cork oak in Morocco. Thesis, State, Montpellier, Sharifian, Botanical Series, 21-462.

[34] Negre, R. (1966) Therophytes. Memory, Society, Botany, F1, 92-108.

[35] Daget, Ph. (1980) A current element of the characterization of the Mediterranean world: Climate. Naturalia Monspeliensia, 1, 101-126.

[36] Aïdoud, A. (1983) Contribution to the study of steppe ecosystems of South Orany: Phytomass, primary productivity and pastoral applications. Thesis, Third Cycle, University of Science \& Technology, H. Boumediene, Algiers.

[37] Barbero, M. and Quezel, P. (1989) Structures, architectures and sclerophyllous forest fire prevention. Bulletin Ecology, 20, 7-14. 
[38] Ellenberg, H., Mueller, A. and Dombois, D. (1968) Akey to Raunkiaer plant fee forms with revised. Subdivision, Berlin, Geobotanic, Institute, ETH, Stiftg. Rübel, Zürich, 37, 56-73.

[39] Orshan, G. (1984) Monocharacter growth form types as a tool in an analytic. Synthetic study of growth forms in Mediterranean type ecosystems, Aproposal for an inter-regional program. Ecologia Mediterranea, 8, 159-171.

[40] Gamisans, J. and Guber, H. (1980) The plant communities of Niolo (Corsica). Ecologia Mediterranea, 11, 101113.

[41] Grime, J.P. (1997) Evidence for the existence of three primary strategies in plants and its relevance to ecological and evolutionary theory. The American Naturalist, 111, 1169-1194. doi:10.1086/283244

[42] Floret, C., Galan, M.J., Lefloch, E. and Romane F. (1992) Dynamics of holm oak (Quercus ilex L.) coppies after clear cutting in sounthen France. Vegetation 99-100. In: Romane, F. and Terradas, J., Eds., Quercus ilex L. Ecosystems, Function, Dynamics and Management. Kluwer Academy Publischers, Belguin, 97-105.

[43] Loisel, R. and Gamila, H. (1993) Translation effects of clearing on forest ecosystems by forest pre-disturbance index. Annales de la Societe des Sciences Naturelles et d'Archeologie de Toulon et du Var, 45, 123-132.

[44] El-Hamrouni, A. (1992) Forest vegetation and pre-forest of Tunisia: Typology and elements for managing. Thesis, Es-Science, Faculty of Sciences and Techniques of Saint Jérôme, University of Aix-Marseille III, France, 220.

[45] Wilson, A.D. (1986) Principles of grazing management systems. In rangelands: A resource under siege. Proceedings of the 2nd International Rangeland Congress, Canberra, 1986, 221-225.

[46] Quezel, P., Gamisans, J. and Guber, M. (1980) Biogeography and introduction of Mediterranean floras. Naturalia
Monspeliensia, 41-51.

[47] Quezel, P. (1983) Flora and vegetation of North Africa, their significance through the origin, evolution and migration of flora and vegetation structures past. Bothalia, 14, 411-416.

[48] Heywood, V. (1995) The Mediterranean flora in the context of World biodiversity. Ecologia Mediterranea, 21, 1118.

[49] Vela, E. and Benhouhou, S. (2007) Evaluation of a new hotspot of plant biodiversity in the Mediterranean basin (North Africa). Comptes Rendus Biologies, 330, 589-605. doi:10.1016/j.crvi.2007.04.006

[50] Zeraia, L. (1981) Test of comparative interpretation of ecological data, phenological and production Suberowoody in cork oak forests of crystalline province (southern France) and Algeria. Thesis, Aix Marseille Université, Marseille.

[51] Stevenson, A.C., Skinner, J., Hollis, G.E. and Smart, M. (1988) The El Kala National Park and Environs, Algeria: An ecological evaluation. Environmental Conservation, 15, 335-348. doi:10.1017/S0376892900029830

[52] Belouahem, D., Belouahem, F. and Belair, G. (2009) Floristic biodiversity and vulnerability of Numidia Aulnaies glutinous Algeria (N-E Algeria). European Journal of Scientific Research, 32, 329-361.

[53] Yahi, N., Djellouli Y. and De Foucault, B. (2008) Floristic diversity and biogeography of the cedar forests of Algeria. Acta Botanica Gallica, 155, 403-414.

[54] Letreuche-Belarouci, A., Medjahdi, B., Letreuche-Belarouci, N. and Benabdeli, K. (2009) Floristic diversity of cork oak forests of the park national de Tlemcen (Algeria). Acta Botanica Malacitana, 34, 1-13.

[55] Medail, F. and Quezel, P. (1997) Hot-spot analysis for conservation of plants biodiversity in the Mediterranean Basin. Annals of the Missouri Botanical Garden, 84, 121127. doi: $10.2307 / 2399957$ 